\title{
CHEMOSPHERE
}

\section{Effects of EDTA on solubility of cadmium, zinc, and lead and their uptake by rainbow pink and vetiver grass}

\author{
Hung-Yu Lai, Zueng-Sang Chen * \\ Graduate Institute of Agricultural Chemistry, National Taiwan University, Taipei 106-17, Taiwan
}

Received 27 February 2003; received in revised form 11 September 2003; accepted 1 November 2003

\begin{abstract}
Rainbow pink (Dianthus chinensis), a potential phytoextraction plant, can accumulate high concentrations of Cd from contaminated soils. Vetiver grass (Vetiver zizanioides) has strong and long root tissues and is a potential phytostabilization plant since it can tolerate and grow well in soils contaminated with multiple heavy metals. Soil was moderately artificially contaminated by cadmium $(20 \mathrm{mg} / \mathrm{kg})$, zinc $(500 \mathrm{mg} / \mathrm{kg})$, and lead $(1000 \mathrm{mg} / \mathrm{kg})$ in pot experiments. Three concentrations of $\mathrm{Na}_{2}-$ EDTA solution $(0,5$, and $10 \mathrm{mmol} / \mathrm{kg}$ soil) were added to the contaminated soils to study the influence of EDTA solution on phytoextraction by rainbow pink or phytostabilization by vetiver grass. The results showed that the concentrations of $\mathrm{Cd}, \mathrm{Zn}$, and $\mathrm{Pb}$ in a soil solution of rainbow pink significantly increased following the addition of EDTA $(p<0.05)$. The concentrations of $\mathrm{Cd}$ and $\mathrm{Pb}$ in the shoots of rainbow pink also significantly increased after EDTA solution was applied $(p<0.05)$, but the increase for $\mathrm{Zn}$ was insignificant. EDTA treatment significantly increased the total uptake of $\mathrm{Pb}$ in the shoot, over that obtained with the control treatment $(p<0.001)$, but it did not significantly increase the total uptake of $\mathrm{Cd}$ and $\mathrm{Zn}$. The concentrations of $\mathrm{Zn}$ and $\mathrm{Pb}$ in the shoots of rainbow pink are significantly correlated with those in the soil solution, but no relationship exists with concentrations in vetiver grass. The toxicity of highly contaminating metals did not affect the growth of vetiver grass, which was found to grow very well in this study. Results of this study indicate that rainbow pink can be considered to be a potential phytoextraction plant for removing $\mathrm{Cd}$ or $\mathrm{Zn}$ from metal-contaminated soils, and that vetiver grass can be regarded as a potential phytostabilization plant that can be grown in a site contaminated with multiple heavy metals. (c) 2003 Elsevier Ltd. All rights reserved.
\end{abstract}

Keywords: EDTA; Rainbow pink; Vetiver grass; Phytoextraction; Phytostabilization

\section{Introduction}

Phytoremediation is the use of plants to remediate organic, inorganic or nuclear pollutants in contaminated sites. Phytoremediation techniques include phytoextraction, phytostabilization, phytovolatilization, phytodegradation and phytofiltration (Salt et al., 1995; Chaney et al., 1997; Lombi et al., 1998; Wenzel et al., 1999; Garbisu and Alkorta, 2001). Of these techniques,

\footnotetext{
${ }^{*}$ Corresponding author. Tel.: +886-2-2369-8349; fax: +8862-2392-4335.

E-mail address: soilchen@ccms.ntu.edu.tw (Z.-S. Chen).
}

phytoextraction and phytostabilization are used to remediate inorganic-contaminated soil, especially soil contaminated by heavy metals. Phytoextraction accumulates toxic metals from contaminated soil into the aboveground tissue of higher plants, which are then harvested and incinerated and/or buried (Kumar et al., 1995; Chaney et al., 1997; Wenzel et al., 1999; Garbisu and Alkorta, 2001). Phytostabilization uses the dense root system of the plant to physically stabilize the contaminated soil, protecting against erosion by wind and water, thereby reducing the risk to the environment by the leaching of pollutants into groundwater (Salt et al., 1995; Chaney et al., 1997; Garbisu and Alkorta, 2001; Pulford and Watson, 2003). 
Over 400 plant species of hyperaccumulators from all over the world can accumulate high concentrations of metals at contaminated sites (Baker et al., 2000), but many of them have a low growth rate and very low biomass; they therefore need much time to remove contaminants from soils. Two strategies, one involving chelating agents and the other involving genetic engineering, are being developed to increase the phytoextraction of metals with higher biomass or by transgenic plants. Synthesized chelating agents, such as ethylenedinitrilotetraacetic acid (EDTA), diethylenetrinitrilopentaacetic acid (DTPA), hydroxyethylenediaminetriacetic acid (HEDTA), trans-1,2-cyclohexylenedinitrilotetraacetic acid (CDTA), and ethylenebis(oxyethylenetrinitrilo)tetraacetic acid (EGTA), were applied to metal-contaminated soil to increase the mobility and bioavailability of the metal in the soils and also to increase the amount of heavy metals accumulated in the upper parts of plants (Huang and Cunningham, 1996; Blaylock et al., 1997; Huang et al., 1997; Ebbs and Kochian, 1998; Wu et al., 1999). These results revealed that adding synthetic chelating agents can increase both the solubility of metal in soil solution and the concentration of metal in the shoots of plants. However, in soils contaminated with multiple metals, the application of synthetic chelating agents can reduce both the biomass of the plant and the total amount of metal removed because the high concentrations of other metals in the soil solution are toxic to the plant (Chen and Cutright, 2001; Lombi et al., 2001). Synthetic chelating agents at high concentrations can also be toxic to plants (Cooper et al., 1999). Applying synthetic chelating agents to soils contaminated by multiple metals represents another challenge for chemical enhancement of the phytoextraction by plants grown on contaminated sites.

Using garden plants to remove metals from contaminated soils is a popular and satisfactory strategy, because it recovers the contaminated sites to their natural condition and also generates economic value if appropriate flower species are cultivated. Chen and Lee (1997) reported that when rainbow pink was grown in a contaminated site in northern Taiwan for five weeks, the $\mathrm{Cd}$ concentration in the shoot of the plant increased from 1.56 (under the control treatment) to $115 \mathrm{mg} / \mathrm{kg}$, and the total $\mathrm{Cd}$ total uptake was about $100 \mathrm{~g} / \mathrm{ha} / \mathrm{yr}$. These findings showed that this plant can accumulate a high concentration of $\mathrm{Cd}$. Moreover, the accumulated $\mathrm{Cd}$ concentration can reach the threshold $(100 \mathrm{mg} \mathrm{Cd} /$ $\mathrm{kg}$ ) of a hyperaccumulator of Cd (Baker et al., 2000).

Vetiver grass (Vetiver zizanioides) is a fast-growing plant that tolerates various environments, including soil $\mathrm{pH}$ values between 3.0 and 10.5 and temperatures from 14 to $55^{\circ} \mathrm{C}$. It also effectively controls erosion of soil by water (NRC, 1993; Truong et al., 1995). In soils contaminated with multiple elements, high concentrations of heavy metals do not affect the plant's growth
(Roongtanakiat and Chairoj, 2002). In previous study, from 250 to $750 \mathrm{mg} \mathrm{Pb} / \mathrm{kg}$ accumulated in the shoots of vetiver grass when the grass was grown in $\mathrm{Pb}$-contaminated sandy loam soil, but a high concentration of $\mathrm{Pb}$ reduced the growth, biomass, and total chlorophyll content of the plant (Chantachon et al., 2002).

The objectives of this study are (i) to identify the effects of adding EDTA on the concentration of heavy metals in soil solution when rainbow pink and vetiver grass are grown in artificially polluted soils contaminated with $\mathrm{Cd}, \mathrm{Zn}$, and $\mathrm{Pb}$ in the soils of northern Taiwan, and (ii) to evaluate the effect of adding EDTA on the phytoextraction of rainbow pink and on the phytostabilization of vetiver grass.

\section{Materials and methods}

\subsection{Characteristics of pot-tested soils}

A rural soil, artificially contaminated by $\mathrm{Cd}, \mathrm{Zn}$, and $\mathrm{Pb}$, was used in the pot experiments. The soil's $\mathrm{pH}$ value was determined using glass electrodes in a soil to water ratio of 1:1 (McLean, 1982). The soil particle size distribution was analyzed using the pipette method (Gee and Bauder, 1986). Organic carbon content was determined by the Walkley-Black wet combustion method (Nelson and Sommers, 1982). Cation exchange capacity (CEC) was determined using the ammonium acetate method (Rhoades, 1982; Thomas, 1982). The total concentration of $\mathrm{Cd}, \mathrm{Zn}$, and $\mathrm{Pb}$ in soils were digested by aqua regia and determined by atomic absorption spectrometry (Hitachi 180-30 type) (EPA/ROC, 2002).

\subsection{Pre-treatment of the soil}

The soil used in this study was collected from a Cdcontaminated site in northern Taiwan. The surface soil $(0-20 \mathrm{~cm})$ of the contaminated site was sampled, airdried, and ground to pass through a $2 \mathrm{~mm}$ sieve. It was stored in large plastic bottles for laboratory analysis and pot experiments. Three salt solutions, $\mathrm{Cd}\left(\mathrm{NO}_{3}\right)_{2} 4 \mathrm{H}_{2} \mathrm{O}$, $\mathrm{ZnO}$, and $\mathrm{Pb}\left(\mathrm{NO}_{3}\right)_{2}$, were added to the air-dried soil to control the total concentration (as individual element concentration) of the three metals at $20 \mathrm{mg} \mathrm{Cd} / \mathrm{kg}, 500$ $\mathrm{mg} \mathrm{Zn} / \mathrm{kg}$, and $1000 \mathrm{mg} \mathrm{Pb} / \mathrm{kg}$. The treated soils were wetted for two weeks by adding deionized water to maintain water content of $60 \%$ of the total water-holding capacity to enable the added heavy metal salts to reach a steady-state. Then, the soils were dried at room temperature for approximately four weeks. The artificially contaminated soil was subjected to three cycles of wet and dry processes before pot experiments were conducted (Blaylock et al., 1997). 


\subsection{Pot experiments and laboratory analysis}

Each pot contained $3.5 \mathrm{~kg}$ (dry weight) of artificially contaminated soil. Two rhizon soil moisture samplers (RSMS) were put in each pot at a depth of around $10 \mathrm{~cm}$ below the surface of the soil. Two seedlings of rainbow pink (Dianthus chinensis) or ten seedlings of vetiver grass (Vetiver zizanioides) were planted in each pot. The pot experiments were conducted in a greenhouse using a randomized complete block design (RCBD) with a number of treatments and three replicates. The soil moisture content was maintained at $60 \%$ of the waterholding capacity, by weighing and adding deionized water every two days.

Three concentrations of $\mathrm{Na}_{2}$-EDTA solution $(0,5$, and $10 \mathrm{mmol} / \mathrm{kg}$ soil) were added to the contaminated soils after seven days of planting. The growth conditions and observed symptoms of toxicity, displayed by the plants, were also recorded. Tested plants were harvested seven days after the EDTA solution was first added to the pot. The harvested plants were oven-dried at $60{ }^{\circ} \mathrm{C}$ for $72 \mathrm{~h}$, weighed, and ground to $0.5 \mathrm{~mm}$ for analysis. Then, $0.2 \mathrm{~g}$ of the plants were digested by the $\mathrm{H}_{2} \mathrm{SO}_{4} /$ $\mathrm{H}_{2} \mathrm{O}_{2}$ digestion method (Jones and Case, 1990). The digested solutions were filtered through Whatman No. 42 filter paper, and then diluted with deionized water to a volume of $50 \mathrm{ml}$ in a flask. The $\mathrm{Cd}, \mathrm{Zn}$, and $\mathrm{Pb}$ concentrations were determined by atomic absorption spectrometry (Hitachi 180-30 type).

Soil solutions were also collected directly by an RSMS before harvesting. The bioavailable concentrations of $\mathrm{Cd}, \mathrm{Zn}$, and $\mathrm{Pb}$ in contaminated soils were evaluated from the concentrations of heavy metals in the soil solution, which were determined by inductively coupled plasma optical emission spectrometry (ICPOES) (Perkin-Elmer 2000 DV).

\subsection{Statistics}

The variance and significance of the differences among concentrations of $\mathrm{Cd}, \mathrm{Zn}$, and $\mathrm{Pb}$ in the soil solutions and the plants were analyzed by ANOVA. Statistical significance was defined as $p=0.05$.

\section{Results and discussion}

\subsection{Soil characteristics}

Table 1 shows the physical and chemical characteristics of the studied soil. The studied soil texture was silty clay with a moderate cation exchange capacity of $13.9 \mathrm{cmol}_{(+)} / \mathrm{kg}$ soil. The original total concentrations of the metals in the contaminated soil, digested by aqua regia, were $2.58 \pm 0.08 \mathrm{mg} \mathrm{Cd} / \mathrm{kg}, 80.0 \pm 5.32 \mathrm{mg} \mathrm{Zn} / \mathrm{kg}$ and $31.3 \pm 2.09 \mathrm{mg} \mathrm{Pb} / \mathrm{kg}$, respectively. After the soil was spiked with salts of heavy metals, the final total concentrations of the elements were $19.0 \pm 1.74 \mathrm{mg} \mathrm{Cd} / \mathrm{kg}$, $503 \pm 44.1 \mathrm{mg} \mathrm{Zn} / \mathrm{kg}$, and $931 \pm 54.7 \mathrm{mg} \mathrm{Pb} / \mathrm{kg}$, respectively.

\subsection{Concentrations of metals in soil solution in pot experiments}

The results indicated that the $\mathrm{Cd}, \mathrm{Zn}$, and especially the $\mathrm{Pb}$ concentrations in the soil solution collected from rainbow pink (Dianthus chinensis) were simultaneously and significantly increased $(p<0.05)$ by adding 5 or 10 $\mathrm{mmol} / \mathrm{kg}$ EDTA solution, except for $\mathrm{Cd}$ in $10 \mathrm{mmol} / \mathrm{kg}$ EDTA treatment (Fig. 1). In previous studies, the application of EDTA solution efficiently increased the soluble or exchangeable fraction of metals which was available to plants (Blaylock et al., 1997; Barona et al., 2001; Chen and Cutright, 2001). The results of this study were similar to those of previous studies. Cd concentrations in the soil solutions did not significantly increase when $10 \mathrm{mmol}$ EDTA/kg soil was applied, perhaps because the high variation of $\mathrm{Cd}$ concentrations in the soil solutions after $10 \mathrm{mmol}$ EDTA/kg soils was added. The $\mathrm{Pb}$ concentration in the soil solution significantly increased from $5.93 \pm 1.27$ (in the control treatment) to $90.4 \pm 12.5 \mathrm{mg} \mathrm{Pb} / 1$ (15-fold) and also from $5.93 \pm 1.27$ to $252 \pm 182 \mathrm{mg} \mathrm{Pb} / \mathrm{l}$ (42-fold) when 5 and $10 \mathrm{mmol}$ of EDTA $/ \mathrm{kg}$ soils were added, respectively $(p<0.001)$ (Fig. 1c). After $10 \mathrm{mmol}$ EDTA/kg soils had been added for 21 days, $\mathrm{Zn}$ and $\mathrm{Pb}$ concentrations in the soil solution were approximately double and 30 times those of the control (data not shown). EDTA solution can

Table 1

The physical and chemical properties of studied soil

\begin{tabular}{lllllll}
\hline $\begin{array}{l}\mathrm{pH} \\
\left(\mathrm{H}_{2} \mathrm{O}\right)\end{array}$ & $\begin{array}{l}\text { O.C. } \\
(\mathrm{g} / \mathrm{kg})^{\mathrm{a}}\end{array}$ & Texture & $\begin{array}{l}\mathrm{CEC} \\
\left(\mathrm{cmol}_{(+)} / \mathrm{kg} \mathrm{soil}\right)^{\mathrm{b}}\end{array}$ & \multicolumn{2}{l}{ Metal concentration $(\mathrm{mg} / \mathrm{kg})^{\mathrm{c}}$} \\
\cline { 5 - 8 } & 16.9 & Silty clay $^{\mathrm{d}}$ & 13.9 & $\mathrm{Cd}$ & $\mathrm{Zn}$ & $\mathrm{Pb}$ \\
\hline 4.9 & 16 & & & $2.58 \pm 0.08$ & $80.0 \pm 5.32$ & $31.3 \pm 2.09$ \\
\hline
\end{tabular}

${ }^{\mathrm{a}}$ O.C.: organic carbon.

${ }^{\mathrm{b}} \mathrm{CEC}$ : cation exchangeable capacity.

${ }^{\mathrm{c}}$ The total content of $\mathrm{Cd}, \mathrm{Zn}$, and $\mathrm{Pb}$ in the original soil was digested by aqua regia.

${ }^{\mathrm{d}}$ Sand $14.2 \%$, silt $46.2 \%$, and clay $39.6 \%$. 


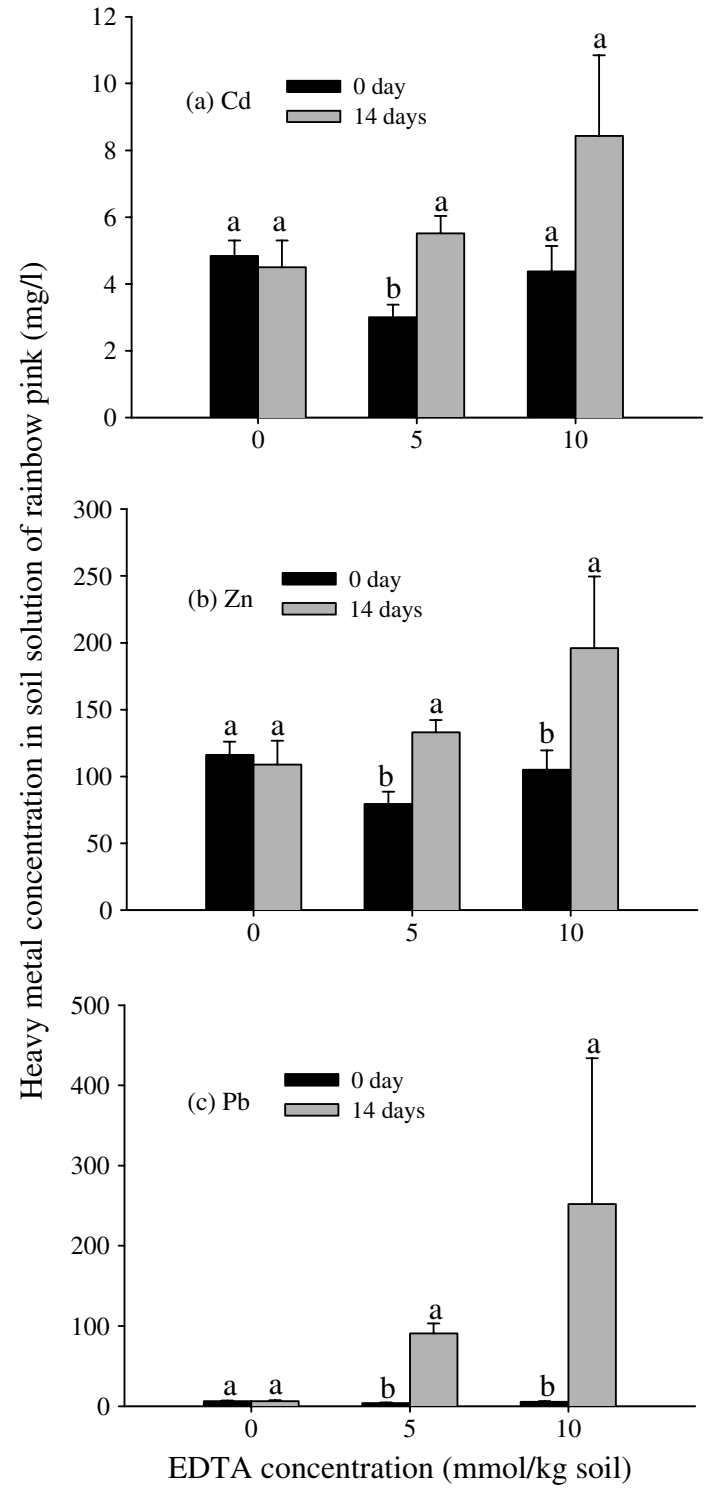

Fig. 1. The concentrations of: (a) $\mathrm{Cd}$; (b) $\mathrm{Zn}$ and (c) $\mathrm{Pb}$ in the soil solution of rainbow pink, which was sampled at the 0 day and 14th day after planting with the different concentrations of EDTA treatments. The probability level of significant difference is at $p=0.05(n=3)$.

remain in the soil for a long period. Lombi et al. (2001) found that EDTA can be found in the soil pore water five months after EDTA solution is applied. This study, however, finds that the three heavy metals can remain in soil solution for more than 21 days after $10 \mathrm{mmol} / \mathrm{kg}$ of EDTA is added, showing also that EDTA treatment can increase the mobility of metals in the contaminated soils. This finding also implies a potential risk of polluting groundwater when EDTA is used to mobilize metals in contaminated sites.

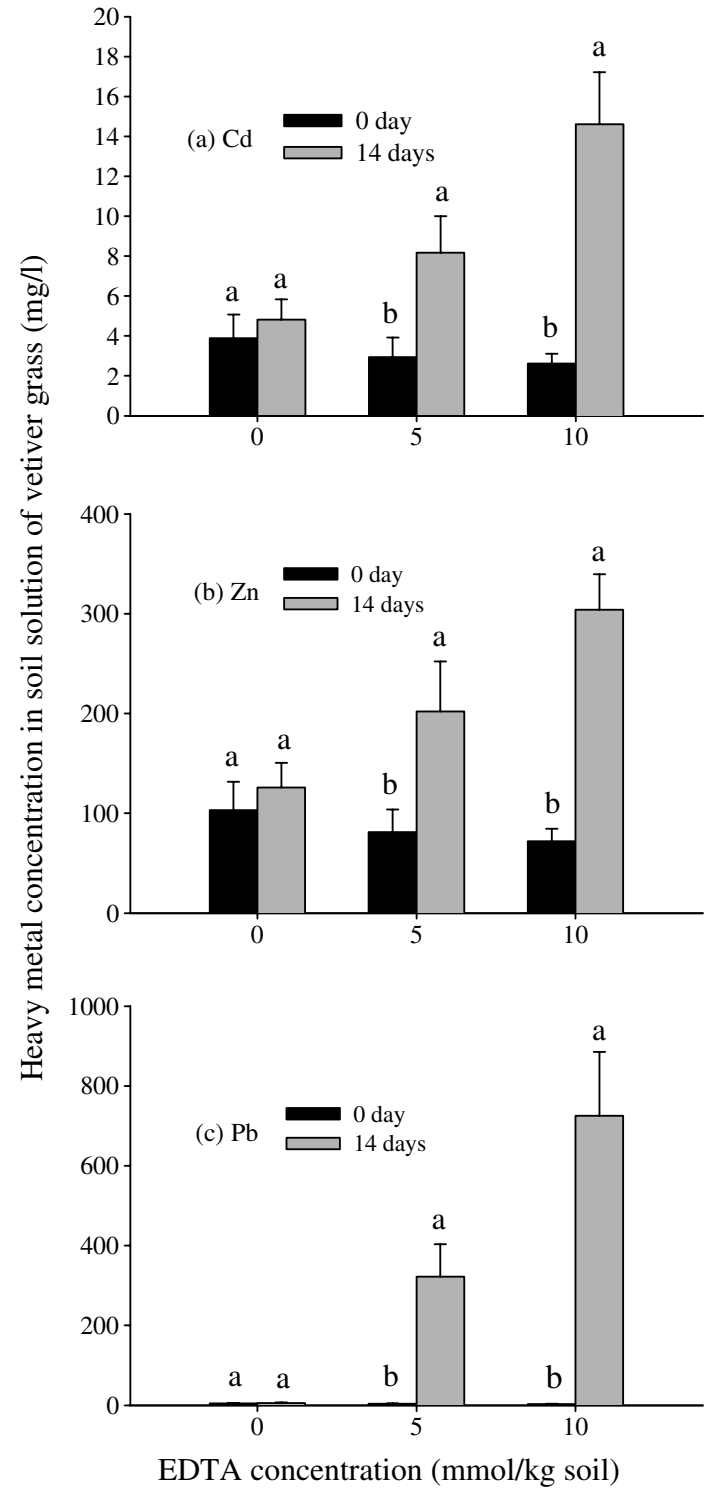

Fig. 2. The concentrations of: (a) $\mathrm{Cd}$; (b) $\mathrm{Zn}$, and (c) $\mathrm{Pb}$ in the soil solution of vetiver grass, which was sampled at the 0 day and 14th day after planting with the different concentrations of EDTA treatments. The probability level of significant difference is at $p=0.05$. Replicates $(n)=3$.

The vetiver grass (Vetiver zizanioides) exhibits the same trends as those obtained in the rainbow pink pot experiments. Adding 5 or $10 \mathrm{mmol}$ EDTA/kg soils can significantly increase the concentration of $\mathrm{Cd}$ and $\mathrm{Zn}$ in soil solution, and especially that of $\mathrm{Pb}(p<0.05)$ (Fig. 2). The concentration of $\mathrm{Pb}$ in the soil solution was significantly increased from $5.79 \pm 1.34$ (in the control treatment) to $322 \pm 81.7 \mathrm{mg} \mathrm{Pb} / 1$ (56-fold) and to $725 \pm 160 \mathrm{mg} \mathrm{Pb} / \mathrm{l}$ (125-fold) when 5 and $10 \mathrm{mmol} / \mathrm{kg}$ soil of EDTA solution were added, respectively $(p<0.05)$ 
(Fig. 2c). These results indicate that the EDTA solution affectively increased the concentration of metal, especially for $\mathrm{Pb}$, in the soil solution. The findings are consistent with those obtained following the application of EDTA treatments in other studies of contaminated soils (Blaylock et al., 1997; Huang et al., 1997; Wu et al., 1999; Luo et al., 2000; Chen and Cutright, 2001; Lombi et al., 2001). The differences of the chelating effects between EDTA and metals are reflected by the formation constant $\left(K_{\mathrm{f}}=19.0\right)$ of the $\mathrm{Pb}$-ligand complexes, which exceeds those of the Cd-ligand complexes $\left(K_{\mathrm{f}}=17.4\right)$ and the $\mathrm{Zn}$-ligand complexes $\left(K_{\mathrm{f}}=17.5\right)$ (Martell and Smith, 1974, 1982).

\subsection{Effects of EDTA treatments on uptake of metals by rainbow pink}

The concentration of $\mathrm{Cd}$ in the shoots of rainbow pink was significantly increased after $10 \mathrm{mmol} / \mathrm{kg}$ of EDTA solution was added $(p<0.05)$ (Fig. 3a). The Zn concentration in the shoots of plants also increased from around $700 \pm 132 \mathrm{mg} / \mathrm{kg}$ to $1200 \pm 369 \mathrm{mg} / \mathrm{kg}(p>0.05)$ (Fig. 3b). The $\mathrm{Pb}$ concentration in the plants was not detectable (ND, below detection limit) when no EDTA treatment was applied. However, seven days after 5 or $10 \mathrm{mmol} / \mathrm{kg}$ of EDTA solution was added, the $\mathrm{Pb}$ concentration in the shoots of rainbow pink had increased significantly from ND to $243 \pm 61.3$ or $348 \pm 101 \mathrm{mg} / \mathrm{kg}$, respectively $(p<0.05)$ (Fig. 3c). Lead appears to form the $\mathrm{Pb}$-EDTA complex, which is available for uptake by plants after EDTA is applied (Vassil et al., 1998). Barona et al. (2001) also pointed out that $\mathrm{Pb}$ remained weakly adsorbed to soil components after EDTA solution was applied. Because of the high value of formation constant $\left(K_{\mathrm{f}}=19.0\right)$ of the $\mathrm{Pb}$-ligand complexes (Martell and Smith, 1974, 1982), the Pb-EDTA complex more easily formed after EDTA solution is applied, so the uptake of $\mathrm{Pb}$ by rainbow pink is enhanced. The results of this study indicate that EDTA solution enhances the removal of $\mathrm{Pb}$ from contaminated soil and also the accumulation of $\mathrm{Pb}$ in the shoots, which results are consistent with those of previous studies (Blaylock et al., 1997; Huang et al., 1997; Wu et al., 1999; Chen and Cutright, 2001; Jarvis and Leung, 2001; Lombi et al., 2001; Jarvis and Leung, 2002).

After 5 or $10 \mathrm{mmol} / \mathrm{kg}$ of EDTA solution was applied, no significant influence on the biomass of rainbow pink was observed $(p>0.05)$. The mean dry biomasses of rainbow pink following 0,5 , and $10 \mathrm{mmol} / \mathrm{kg}$ EDTA treatment were $4.91 \pm 0.93,5.35 \pm 0.56$, and $4.08 \pm 0.70$ $\mathrm{g} /$ plant, respectively. With respect to the enhancement of phytoextraction by rainbow pink in metal-contaminated soils, adding 5 or $10 \mathrm{mmol} / \mathrm{kg}$ of EDTA solution did not significantly increase the total removal of $\mathrm{Cd}$ and $\mathrm{Zn}$ from the contaminated soil $(p>0.05)$ (Fig. 4a and b); however, the increase was significant for the removal of

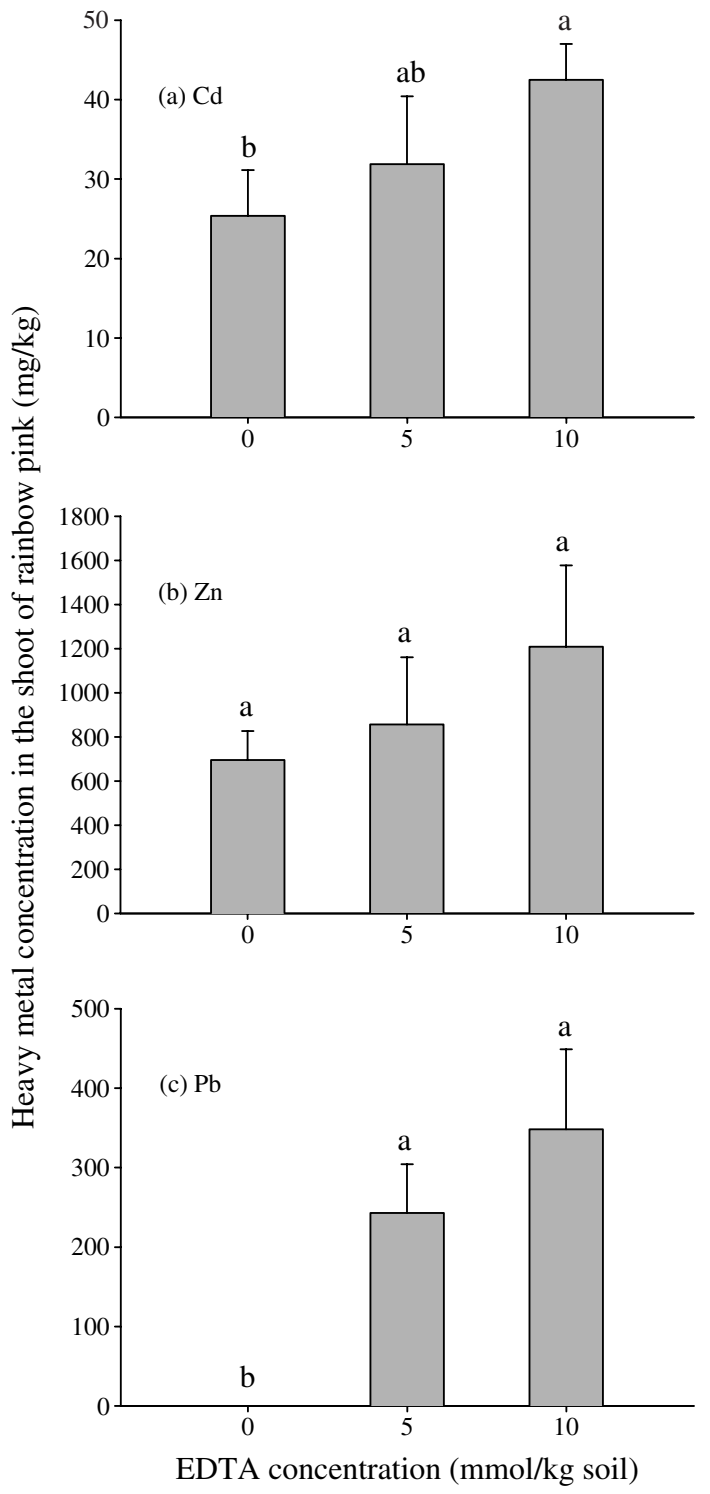

Fig. 3. The concentrations of (a) $\mathrm{Cd}$, (b) $\mathrm{Zn}$, and (c) $\mathrm{Pb}$ in the shoots of rainbow pink, which was harvested at the 14th day after planting with the different concentrations of EDTA treatments. The probability level of significant difference is at $p=0.05$. Replicates $(n)=3$.

$\mathrm{Pb}(p<0.001)$ (Fig. 4c). The total removal of $\mathrm{Pb}$ by the rainbow pink obtained by adding $5 \mathrm{mmol} / \mathrm{kg}$ of EDTA solution did not differ significantly from that obtained by adding $10 \mathrm{mmol} / \mathrm{kg}$ of EDTA solution (Fig. 4c). We propose that rainbow pink is a potential phytoextraction plant for removing $\mathrm{Cd}$ or $\mathrm{Zn}$ from metal-contaminated soil without applying any amendment. The amount removed per harvest is around $0.13 \pm 0.05 \mathrm{mg} \mathrm{Cd} /$ plant, $3.49 \pm 1.37 \mathrm{mg} \mathrm{Zn} /$ plant, and trace Pb/plant (Fig. 4). We also propose that $\mathrm{Pb}$ in contaminated soil is not 


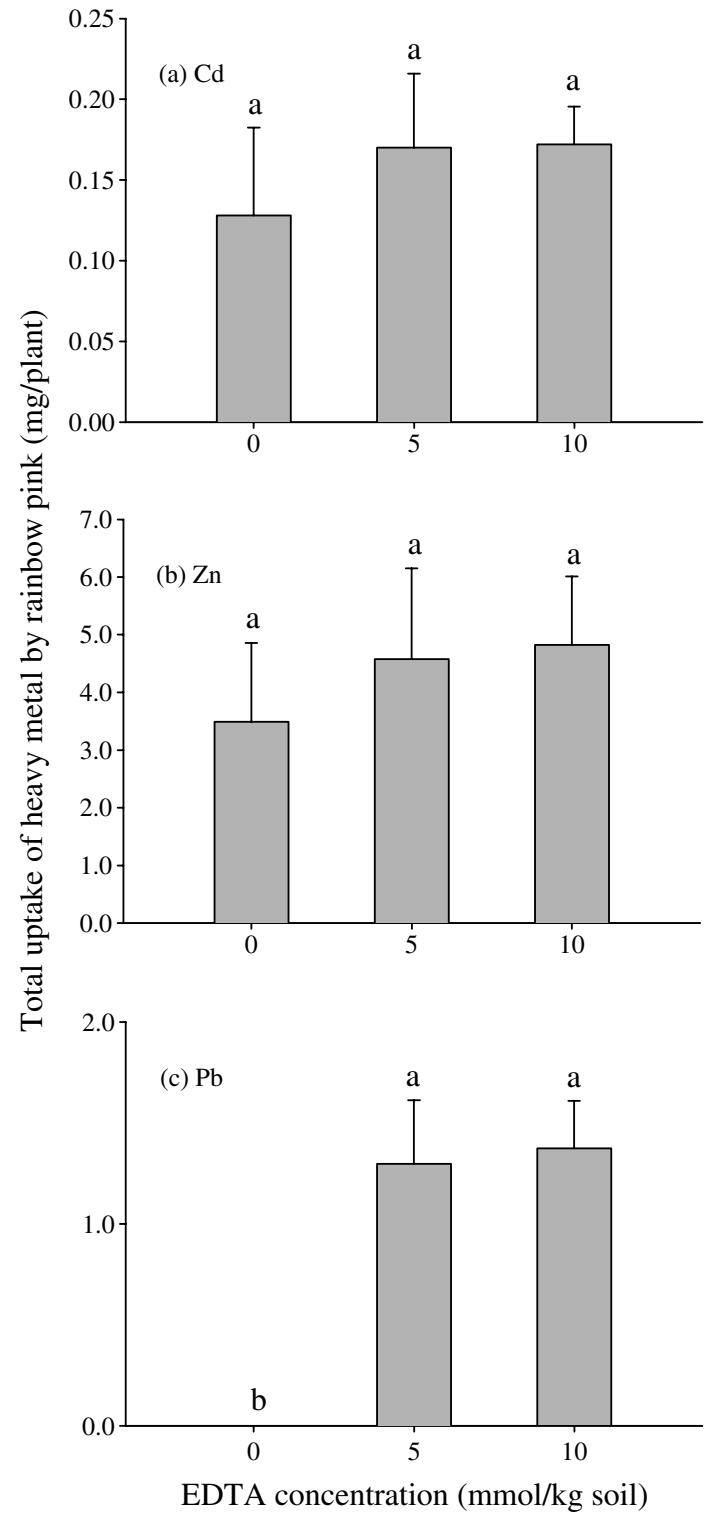

Fig. 4. The total uptake of: (a) $\mathrm{Cd}$; (b) $\mathrm{Zn}$ and (c) $\mathrm{Pb}$ in the shoots of rainbow pink, which was harvested at the 14th day after planting with the different concentrations of EDTA treatments. The probability level of significant difference is at $p=0.05$. Replicates $(n)=3$.

available to rainbow pink, but adding $5 \mathrm{mmol} / \mathrm{kg}$ of EDTA solution significantly increases the bioavailability of $\mathrm{Pb}$ in contaminated soil. Treatment with 5 or $10 \mathrm{mmol} /$ $\mathrm{kg}$ of EDTA solution can promote the removal of $\mathrm{Pb}$ by rainbow pink, far in excess of that obtained from the control treatment in this study. Therefore, further study must be undertaken to identify the critical concentration of EDTA solution between 0 to $5 \mathrm{mmol} / \mathrm{kg}$, to remove a significant amount of $\mathrm{Pb}$ from the contaminated soil.

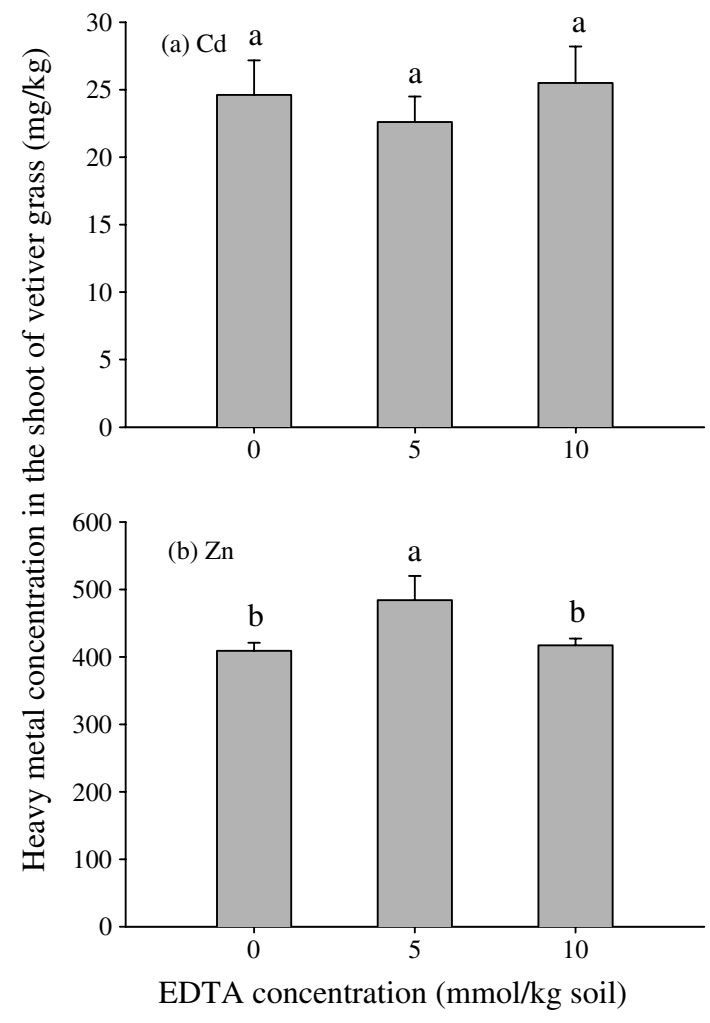

Fig. 5. The concentrations of: (a) $\mathrm{Cd}$ and (b) $\mathrm{Zn}$ in the shoots of vetiver grass, which was harvested at the 14th day after planting with the different concentrations of EDTA treatments. The concentration of $\mathrm{Pb}$ in the shoot is not detectable (ND). The probability level of significant difference is at $p=0.05$. Replicates $(n)=3$.

\subsection{Effects of EDTA treatments on metal uptake by vetiver grass}

Although the concentrations of $\mathrm{Cd}, \mathrm{Zn}$, and $\mathrm{Pb}$ in a solution, in which vetiver grass was planted, changed greatly after EDTA solution was added (Fig. 2), the concentration of $\mathrm{Cd}$ in the shoots of the vetiver grass did not significantly increase, ranging from 20 to $30 \mathrm{mg} / \mathrm{kg}$ (Fig. 5a). The concentration of $\mathrm{Zn}$ in the shoot, ranging from 390 to $520 \mathrm{mg} / \mathrm{kg}$, was significantly increased only by adding $5 \mathrm{mmol} / \mathrm{kg}$ of EDTA solution $(p<0.05)$ (Fig. $5 b)$. Adding $10 \mathrm{mmol} / \mathrm{kg}$ EDTA solution did not increase the $\mathrm{Zn}$ concentration in the shoots of vetiver grass, and the biomass of the vetiver grass decreased from $0.91 \pm 0.04 \mathrm{~g} /$ plant $(0 \mathrm{mmol} / \mathrm{kg}$ of EDTA added $)$ to $0.73 \pm 0.10 \mathrm{~g} / \mathrm{plant}(10 \mathrm{mmol} / \mathrm{kg}$ of EDTA added $)$ $(p>0.05)$. We proposed that the toxicity of metals, resulting from their increased concentration in the soil solution, reduced the concentration of $\mathrm{Zn}$ in the shoots of vetiver grass, but no significant symptoms of toxicity were observed in the pot experiments. Vetiver grass did 
not take up lead in the soil solution, even though the concentration of $\mathrm{Pb}$ in the soil solution increased greatly after EDTA solution was added. The concentration of $\mathrm{Pb}$ in the shoots of vetiver grass was undetectable (ND, under the detection level) following any treatment (data not shown in Fig. 5). We suppose that this species of vetiver grass cannot take up or accumulate the $\mathrm{Pb}$ in its shoot although the concentration of $\mathrm{Pb}$ in soil is as high as $1000 \mathrm{mg} / \mathrm{kg}$. This result also indicates that the growth of vetiver grass is unaffected by the toxicity of the three contaminant metals in the soil in this case study because no symptoms of phytotoxicity were observed. Applying 0,5 , and $10 \mathrm{mmol} / \mathrm{kg}$ of EDTA solution only slightly decreased the biomass of vetiver grass from $0.91 \pm 0.04$ $\mathrm{g} /$ plant to $0.80 \pm 0.20$ and $0.73 \pm 0.10 \mathrm{~g} /$ plant, respectively $(p>0.05)$. The total removal of heavy metals from the contaminated soils was only around $0.015 \mathrm{mg}$ $\mathrm{Cd} / \mathrm{plant}$ and around $0.30 \mathrm{mg} \mathrm{Zn/plant} \mathrm{after} \mathrm{different}$ concentrations of EDTA were added ( $p>0.05)$ (Fig. 6).

\subsection{Relationships between metal concentrations in plants and those in soil solution}

The concentrations of heavy metals in the soil solution extracted by different extractors or directly sampled by RSMS can predict the concentrations in the shoot of plants (Kabata-Pendias et al., 1993; Parkpian et al., 2002). The analysis of data in this study yields correlation coefficients $\left(R^{2}\right)$ between the concentrations of three metals in the soil solution and those in the shoots of rainbow pink of $0.23(\mathrm{Cd}, p>0.05), 0.50(\mathrm{Zn}, p<0.01)$ and $0.91(\mathrm{~Pb}, p<0.001)$ (Fig. 7). These results indicate that significant relationships exist between the concentrations of $\mathrm{Zn}$ and $\mathrm{Pb}$ in the soil solution and those in the shoots of rainbow pink. For vetiver grass, even though the concentrations of $\mathrm{Cd}$ and $\mathrm{Zn}$ in soil solution increased dramatically after the EDTA solution was added, the concentrations of $\mathrm{Cd}$ and $\mathrm{Zn}$ taken up by the shoot were not changed, ranged from 20 to $30 \mathrm{mg} \mathrm{Cd} / \mathrm{kg}$ and ranged from 390 to $520 \mathrm{mg} \mathrm{Zn} / \mathrm{kg}$, respectively $(p>0.05)$ (Fig. 8). Roongtanakiat and Chairoj (2002) found that vetiver grass could take up $2.9 \mathrm{mg} \mathrm{Cd} / \mathrm{kg}$ soil and $253.8 \mathrm{mg} \mathrm{Zn} / \mathrm{kg}$ soil when it was planted in metalcontaminated soil. The concentrations of $\mathrm{Cd}$ and $\mathrm{Zn}$ taken up in this study were much higher than those obtained by Roongtanakiat and Chairoj (2002), implying that this species of vetiver grass is resilient to $\mathrm{Cd}$ and $\mathrm{Zn}$.

\section{Conclusion}

EDTA solution is considered to be a chelating agent that promotes the solubility of metals in contaminated sites. The application of EDTA solution can significantly increase concentrations of $\mathrm{Cd}, \mathrm{Zn}$, and especially

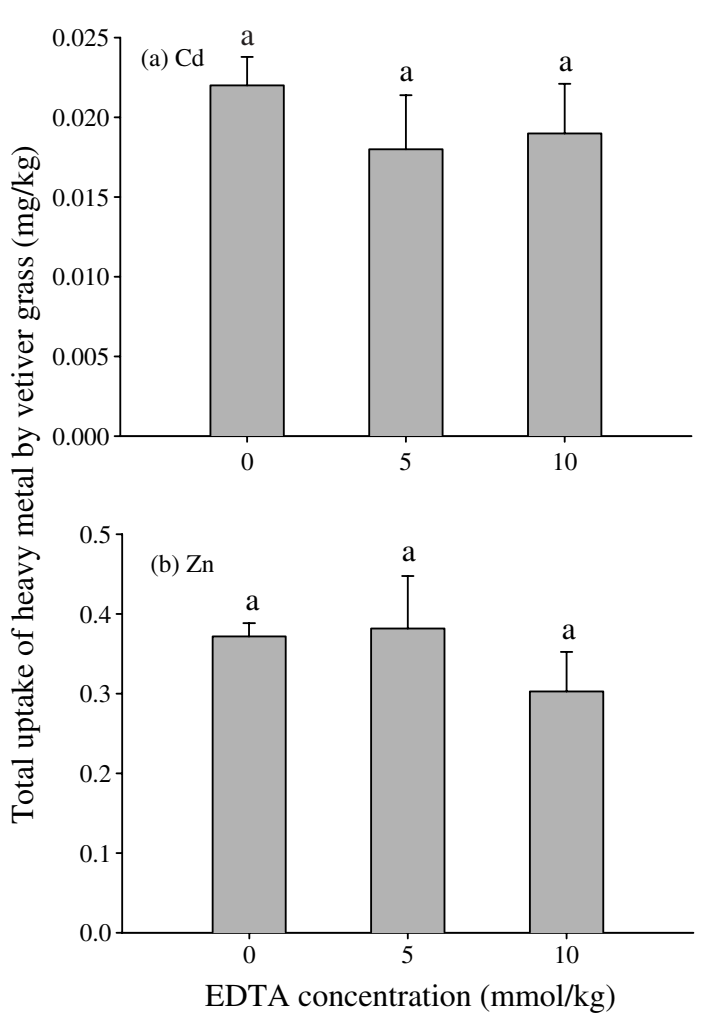

Fig. 6. The total uptake of (a) $\mathrm{Cd}$ and (b) $\mathrm{Zn}$ in the shoots of vetiver grass, which was harvested at the 14th day after planting with the different concentration of EDTA treatments. The concentration of $\mathrm{Pb}$ in the shoot is not detectable (ND). The probability level of significant difference is at $p=0.05$. Replicates $(n)=3$.

$\mathrm{Pb}$ in soil solution moderately contaminated by these three metals $(p<0.05)$. Except in the case of the high variation of $\mathrm{Cd}$ concentration in the soil solution of rainbow pink after $10 \mathrm{mmol} / \mathrm{kg}$ of EDTA solution is added, applying EDTA solution at a high concentration $(10 \mathrm{mmol} / \mathrm{kg})$ increases the concentration of the metals in the soil solution more than is obtained by applying EDTA at a lower concentration $(5 \mathrm{mmol} / \mathrm{kg})$, but the EDTA solution may contribute to the pollution of the groundwater.

Adding EDTA solution efficiently and significantly increases the concentrations of $\mathrm{Cd}$ and $\mathrm{Pb}$ in the shoots of rainbow pink. Treatment with $5 \mathrm{mmol} / \mathrm{kg}$ of EDTA solution significantly increases the concentration of $\mathrm{Zn}$ only in the shoots of the vetiver grass $(p<0.05)$. Adding EDTA solution also significantly increases the total removal of $\mathrm{Pb}$ by rainbow pink $(p<0.001)$, but did not affect the total removal of $\mathrm{Cd}, \mathrm{Zn}$, and $\mathrm{Pb}$ by vetiver grass.

The results of this study indicate that the concentrations of $\mathrm{Zn}$ and $\mathrm{Pb}$ in soil solution are significantly related 

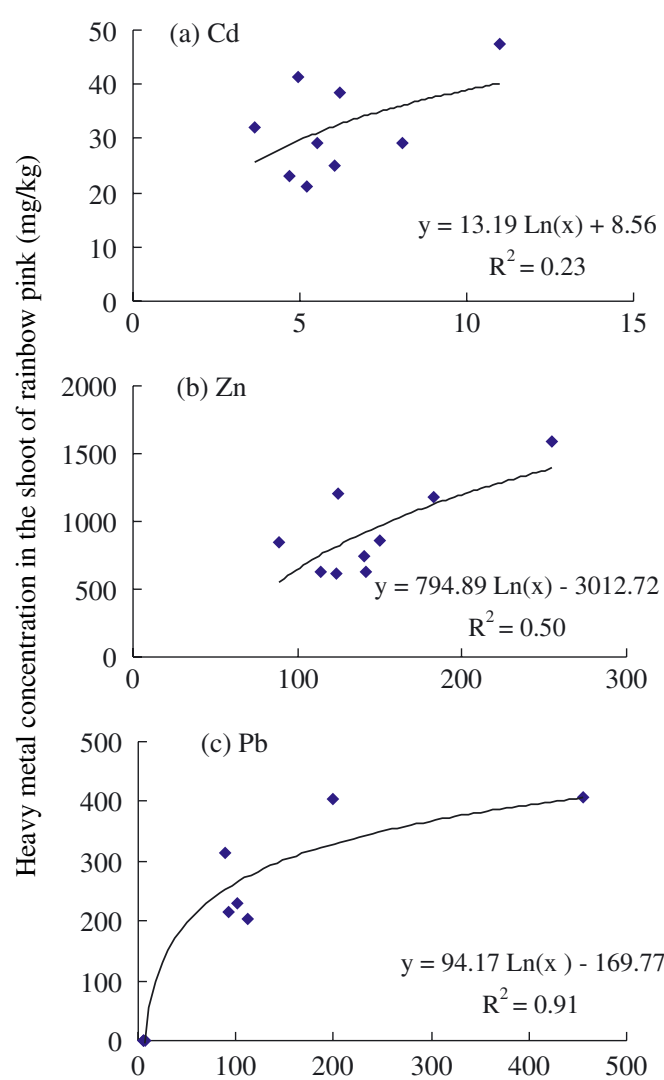

Heavy metal concentration in soil solution $(\mathrm{mg} / \mathrm{l})$

Fig. 7. The relationship between the concentrations of: (a) Cd; (b) $\mathrm{Zn}$ and (c) $\mathrm{Pb}$ in the soil solution and in the shoot of rainbow pink, which was harvested at the 14th days after planting.

to those in the shoots of rainbow pink after treatment with EDTA solution. For vetiver grass, even though the concentrations of $\mathrm{Cd}, \mathrm{Zn}$, and $\mathrm{Pb}$ in the soil solution increased, the concentrations of the metals in the shoots did not change, except for that of $\mathrm{Zn}$, following treatment with $5 \mathrm{mmol} / \mathrm{kg}$ of EDTA solution. Because the concentrations of $\mathrm{Cd}$ and $\mathrm{Zn}$ in the shoot were not significantly changed in both 5 and $10 \mathrm{mmol} / \mathrm{kg}$ of EDTA treatments expected for $\mathrm{Zn}$ in the $5 \mathrm{mmol} / \mathrm{kg}$ EDTA treatment, and the concentration of $\mathrm{Pb}$ was not detected among all the treatments. Therefore, the concentrations of $\mathrm{Cd}, \mathrm{Zn}$, and $\mathrm{Pb}$ in soil solution could not predict the concentrations of metals in the shoots of vetiver grass in this study.

Rainbow pink can accumulate high concentrations of $\mathrm{Cd}$ and $\mathrm{Zn}$ in its shoot naturally even when no EDTA solution is added. However, in this study, the accumulated concentrations of the metals in the shoots are not as high as those reported in a previous study (Chen and Lee, 1997) because of the short period of growth (14 days). Treatment with EDTA solution specifically promoted the uptake of $\mathrm{Pb}$ in the contaminated soil in this

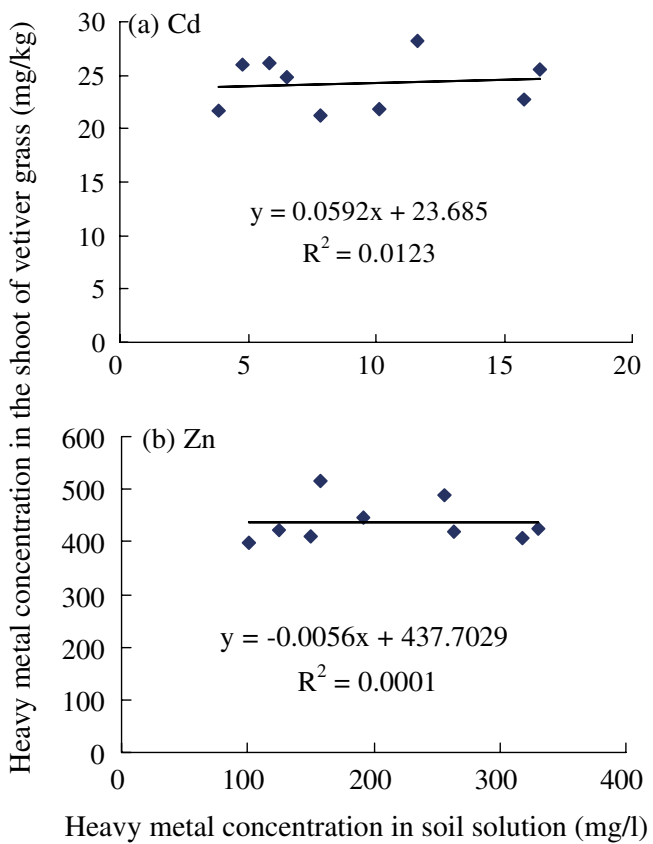

Fig. 8. The relationship between the concentrations of: (a) $\mathrm{Cd}$ and (b) $\mathrm{Zn}$ in soil solution and in the shoot of vetiver grass, which was harvested at the 14th day after planting. The concentration of $\mathrm{Pb}$ in the shoot is not detectable (ND).

study. Further studies must be conducted to increase the period of growth of rainbow pink before EDTA treatment and also to increase the concentrations of metals accumulated.

The results of this study indicate that rainbow pink is a potential phytoaccumulator of $\mathrm{Cd}$ and $\mathrm{Zn}$ from metalcontaminated soil. We suggest that $\mathrm{Pb}$ is not accumulated in rainbow pink, but that adding EDTA solution can significantly increase the concentration of the $\mathrm{Pb}$ in the soil solution and thus its bioavailability in contaminated soil. This study demonstrates that vetiver grass is a potential phytostabilization plant at sites contaminated with several metals.

\section{Acknowledgements}

The authors would like to thank the National Science Council of the Republic of China for financially supporting this research under Contract No. NSC91-2621B-002-003.

\section{References}

Baker, A.J.M., McGrath, S.P., Reeves, R.D., Smith, J.A.C., 2000. Metal hyperaccumulator plants: a review of the ecology and physiology of a biological resource for phyto- 
remediation of metal-polluted soils. In: Terry, N., Bañuelos, G. (Eds.), Phytoremediation of Contaminated Soil and Water. CRC Press LLC, USA, pp. 85-107.

Barona, A., Aranguiz, I., Elías, A., 2001. Metal associations in soils before and after EDTA extractive decontamination: implications for the effectiveness of further clean-up procedures. Environ. Pollut. 113, 79-85.

Blaylock, M.J., Salt, D.E., Dushenkov, S., Zakharova, O., Gussman, C., Kapulnik, Y., Ensley, B.D., Raskin, I., 1997. Enhanced accumulation of $\mathrm{Pb}$ in Indian mustard by soilapplied chelating agents. Environ. Sci. Technol. 31, 860865.

Chaney, R.L., Malik, M., Li, Y.M., Brown, S.L., Brewer, E.P., Angle, J.S., Baker, A.J.M., 1997. Phytoremediation of soil metals. Environ. Biotechnol. 8, 279-284.

Chantachon, S., Kruatrachue, M., Pokethitiyook, P., Tantanasarit, S., Upatham, S., Soontjornsarathool, V., 2002. Phytoextraction of lead from contaminated soil by vetiver grass (Vetiver sp.). Paper no. 2308. In: Proceedings of the 17th World Congress of Soil Science, 14-21 August 2002, Bangkok, Thailand.

Chen, H., Cutright, T., 2001. EDTA and HEDTA effects on $\mathrm{Cd}, \mathrm{Cr}$, and Ni uptake by Helianthus annuus. Chemosphere $45,21-28$.

Chen, Z.S., Lee, D.Y., 1997. Evaluation of remediation techniques on two cadmium-polluted soils in Taiwan. In: Iskandar, I.K., Adriano, D.C. (Eds.), Remediation of Soils Contaminated with Metals. Science Reviews, Northwood, UK, pp. 209-223.

Cooper, E.M., Sims, J.T., Cunningham, S.D., Huang, J.W., Berti, W.R., 1999. Chelate-assisted phytoextraction of lead from contaminated soil. J. Environ. Qual. 28, 1709-1719.

Ebbs, S.D., Kochian, L.V., 1998. Phytoextraction of zinc by oat (Avena sativa), barley (Hordeum vulgare), and Indian mustard (Brassica juncea). Environ. Sci. Technol. 32, 802806.

EPA/ROC, 2002. The digestion methods of heavy metal in soils by aqua regia. Method code No: NIEA S321.62C. Environmental Protection Administration of Taiwan ROC, Taipei, Taiwan.

Garbisu, C., Alkorta, I., 2001. Phytoextraction: a cost-effective plant-based technology for the removal of metals from the environment. Biores. Technol. 77, 229-236.

Gee, G.W., Bauder, J.W., 1986. Particle-size analysis. In: Klute, A. et al. (Eds.), Methods of Soil Analysis. Part 1. Physical and Mineralogical Method, second ed. Agronomy Monograph 9, Madison, WI, USA, pp. 383-412.

Huang, J.W., Cunningham, S.D., 1996. Lead phytoextraction: species variation in lead uptake and translocation. New Phytol. 134, 75-84.

Huang, J.W., Chen, J., Berti, W.R., Cunningham, S.D., 1997. Phytoremediation of lead-contaminated soils: role of synthetic chelates in lead phytoextraction. Environ. Sci. Technol. 31, 800-805.

Jarvis, M.D., Leung, D.W.M., 2001. Chelated lead transport in Chamaecytisus proliferus (L.f.) link ssp. Proliferus var. palmensis (H. Christ): an ultrastructural study. Plant Sci. 161, 433-441.

Jarvis, M.D., Leung, D.W.M., 2002. Chelated lead transport in Pinus radiate: an ultrastructural study. Environ. Exper. Bot. $48,21-32$.
Jones, J.B., Case, V.W., 1990. Sampling, handling, and analyzing plant tissue samples. In: Westerman, et al. (Eds.), Soil Testing and Plant Analysis, third edition. Agronomy Monograph 9, Madison, WI, USA, pp. 404-409.

Kabata-Pendias, A., Piotrowska, M., Dudka, S., 1993. Trace elements in legumes and monocotyledona and their suitability for the assessment of soil contamination. In: Markert, B. (Ed.), Plants as Biomonitors: Indicators for Heavy Metal in the Terrestrial Environment. VCH Verlagsgesellschaft mbH, Weinheim, Germany, pp. 485-494.

Kumar, P.B.A.N., Dushenkov, V., Motto, H., Raskin, I., 1995. Phytoextraction: the use of plants to remove heavy metals from soils. Environ. Sci. Technol. 29, 1232-1238.

Lombi, E., Wenzel, W.W., Adriano, D.C., 1998. Soil contamination, risk reduction and remediation. Land Contam. Reclam. 6, 183-197.

Lombi, E., Zhao, F.J., Dunham, S.J., McGrath, S.P., 2001. Phytoremediation of heavy metal-contaminated soils: natural hyperaccumulation versus chemically enhanced phytoextraction. J. Environ. Qual. 30, 1919-1926.

Luo, Y.M., Wu, L.H., Jiang, X.J., Wu, S.C., Christie, P., 2000. Chelate-enhanced phytoextraction of metal-contaminated soils and its environmental risk. In: Luo, Y.M., McGrath, S.P., Cao, Z.H., Zhao, F.J., Chen, Y.X., Xu, J.M. (Eds.), Proceedings of 2000 International Conference of Soil Remediation, 15-19 October 2000, Hangzhou, China.

Martell, A.E., Smith, R.M., 1974. Critical Stability Constants. Vol. 1: Amino Acids. Plenum Press, New York, USA.

Martell, A.E., Smith, R.M., 1982. Critical Stability Constants. Vol. 5: First Supplement. Plenum Press, New York, USA.

McLean, E.O., 1982. Soil pH and lime requirement. In: Page, A.L. et al. (Eds.), Methods of Soil Analysis. Part 2. Chemical and Microbiological Properties, second ed. Agronomy Monograph 9, Madison, WI, USA, pp. 199224.

NRC (National Research Council), 1993. Vetiver grass: a thin green line against erosion. National Academy Press, Washington, DC, USA.

Nelson, D.W., Sommers, L.E., 1982. Total carbon, organic carbon, and organic matter. In: Page, A.L. et al. (Eds.), Methods of Soil Analysis. Part 2: Chemical and Microbiological Properties, second ed. Agronomy Monograph 9, Madison, WI, USA, pp. 539-580.

Parkpian, P., Leong, S.T., Laortanakul, P., Phuong, N.T.K., 2002. The benefits and risks of using river sediment for Vietnamese agriculture: a case study of the Nhieu Loc canal in Ho Chi Minh city. J. Environ. Sci. Health A 37 (6), 10991122.

Pulford, I.D., Watson, C., 2003. Phytoremediation of heavy metal-contaminated land by trees - a review. Environ. Int. 29, , 529-540.

Rhoades, J.K., 1982. Cation exchange capacity. In: Page, A.L. et al. (Eds.), Methods of Soil Analysis. Part 2. Chemical and Microbiological Properties, second ed. Agronomy Monograph 9, Madison, WI, USA, pp. 149-158.

Roongtanakiat, N., Chairoj, P., 2002. Vetiver grass for remedying soil contaminated with heavy metals. Paper no. 1962. In: Proceedings of the 17th World Congress of Soil Science, 14-21 August 2002, Bangkok, Thailand.

Salt, D.E., Blaylock, M., Kumar, N.P.B.A., Dushenkov, V., Ensley, B.D., Chet, I., Raskin, I., 1995. Phytoremediation: a 
novel strategy for the removal of toxic metals from the environment using plants. Biotechnology 13, 468474.

Thomas, G.W., 1982. Exchangeable cations. In: Page, A.L. et al. (Eds.), Methods of Soil Analysis. Part 2. Chemical and Microbiological Properties, second ed. Agronomy Monograph 9, Madison, WI, USA, pp. 159-166.

Truong, P.N. et al., 1995. Stiffgrass barrier with vetiver grass: a new approach to erosion and sediment control. In: Proceedings of the Downstream Effects of Land Use Conference, Chiang Rai, Thailand.
Vassil, A.D., Kapulnik, Y., Raskin, I., Salt, D.E., 1998. The role of EDTA in lead transport and accumulation by Indian mustard. Plant Physiol. 117, 447-453.

Wenzel, W.W., Lombi, E., Adriano, D.C., 1999. Biogeochemical processes in the rhizosphere: role in phytoremediation of metal-polluted soils. In: Prasad, M.N.V., Hagemeyer, J. (Eds.), Heavy Metal Stress in Plants. Springer, NY, USA, pp. 273-303.

Wu, J., Hsu, F.C., Cunningham, S.D., 1999. Chelate-assisted $\mathrm{Pb}$ phytoremediation: $\mathrm{Pb}$ availability, uptake, and translocation constraints. Environ. Sci. Technol. 33, 1898-1904. 